International Journal of

Supply Chain

Management

(IJSCM)

Effect of Public Procurement Audit on Performance of State Corporations in Kenya

Hannah Wangui Gichuk and Dr. Samson Nyang'au Paul

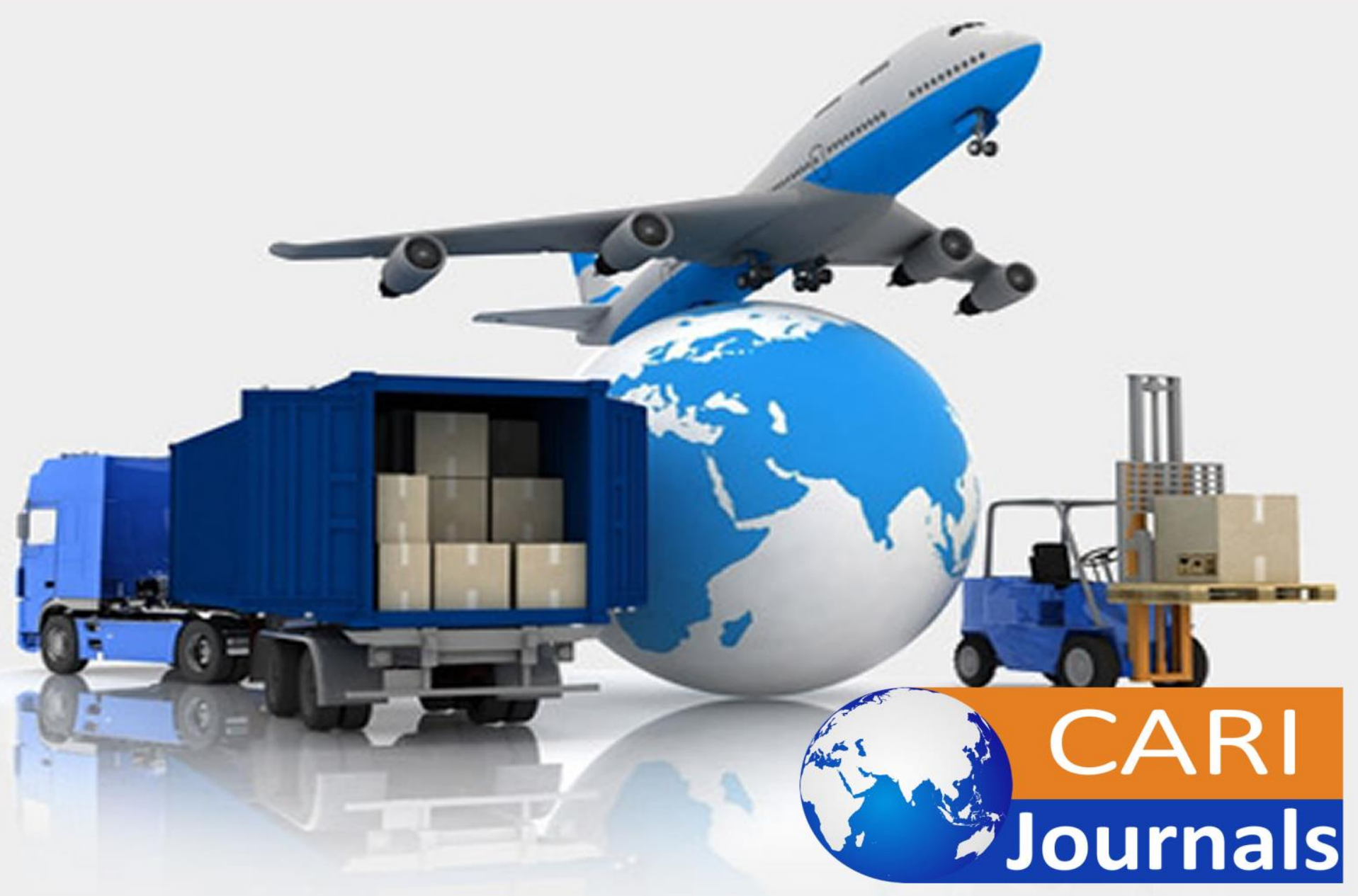




\title{
Effect of Public Procurement Audit on Performance of State Corporations in Kenya
}

\author{
1*Hannah Wangui Gichuki \\ Post Graduate Student: Department of Procurement and Logistics, \\ Jomo Kenyatta University of Agriculture and Technology \\ *Corresponding Author's E-mail: anngichuki2010@gmail.com \\ 2*Dr. Samson Nyang'au Paul \\ Lecturer, Department of Procurement and Logistics \\ Jomo Kenyatta University of Agriculture and Technology
}

\begin{abstract}
Purpose: The purpose of the study was to assess the effect of public procurement audit on performance of state corporations in Kenya.

Methodology: The study employed a descriptive research design, targeting heads of procurement in state corporations. As a rule of thumb when the population is below 200, a study does a census. The researcher preferred this method because it allowed an in-depth study of the subject. Data was collected using self-administered questionnaires. Pilot study was carried out to establish the validity and reliability of the research instruments. The instruments were designed appropriately according to the study objectives. The data collected was analyzed by use of descriptive and inferential statistics. The study used multiple regression and correlation analysis to show the relationship between the dependent variable and the independent variables. The data generated was keyed in and analyzed by use of Statistical Package of Social Sciences (SPSS) version 24 to generate information which was presented using charts, frequencies and percentages.

Results and conclusion: The findings of the study concluded that preparation and planning auditing, information and publicity auditing, evaluation of received tenders auditing, award and execution of contract auditing have a positive relationship with performance of state corporations in Kenya. The independent variables reported $\mathrm{R}$ value of 0.876 indicating that there is perfect relationship between dependent variable and independent variables' square value of 0.768 means that $76.8 \%$ of the corresponding variation in performance of state corporations in Kenya can be explained or predicted by (preparation and planning auditing, information and publicity auditing, evaluation of tenders auditing and award and execution of contract auditing) which indicated that the model fitted the study data. The results of regression analysis revealed that there was a significant positive relationship between dependent variable and independent variable at $(\beta=$ $0.761), \mathrm{p}=0.000<0.05)$.
\end{abstract}

Unique contribution to theory, policy and practice: The study recommended that public institutions should embrace public procurement audit so as to improve performance and further 
International Journal of Supply Chain and Logistics

ISSSN 2520-4661 (Online)

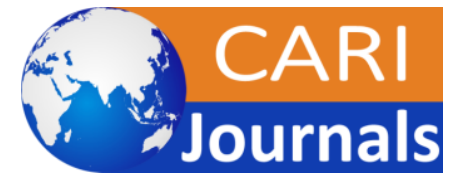

Vol. 4, Issue No.2, pp 104 -128, 2020

www.carijournals.org

researches should to be carried out in other public institutions to find out if the same results can be obtained.

Keywords: Preparation and Planning Auditing, Information and Publicity Auditing, Evaluation, Received Tenders Auditing, Award and Execution of Contract Auditing.

\subsection{INTRODUCTION}

The auditing function has the primary objective of providing reasonable assurance that a set of specified and established criteria have been complied with; and it involves the collection and evaluation of sufficient evidence to determine whether an assertion corresponds with established criteria (Smith, 2017). The two main forms of audits often referred to are: internal and external audits.

The main difference between these two borders on the extent of details; whilst internal audit generally is concerned about the whole operations of an institution with respect to certain five key internal control objectives and not just the financial aspects, external audits mainly focuses on financial control systems that have direct, significant effect on the financial performance of the institution (Schapper \& Paul, 2012).

Drawing from the definitions Richard (2013), public procurement audit can be explained as the process of gathering and evaluating sufficient evidence on government procurement activities to ascertain whether specified laid down procedures have been complied with or not. Public procurement audits are seen as very important to the realization of value addition to government procurement in terms of ensuring accountability, transparency, prevention of improper procurement practices, and improving upon past procurement performance (Wayne State University, 2014).

The basic reason for conducting audits including public procurement audits is to ascertain whether performance measures up to pre-determined standards within defined parameters so that changes can be implemented to improve standards (Hart, Northmore \& Gerhardt, 2016). Some specific reasons for public procurement audits are; to prevent fraud, to provide assurance with regards to effective and efficient operations, to ensure reliable financial reporting, to comply with laws and regulations, to address corruption, and to prevent future mistakes (Krivinsh \& Vilks, 2013). Moreover, public procurement is audited to verify whether there was an actual need for a given procurement; whether the procurement procedure achieved value for money, and whether public procurement regulations were adhered to.

\subsection{Problem Statement}

As the clock ticks, so does demand for better quality, faster delivery, and better overall value increase; leading to a few visionary leaders to start to consciously differentiate between the things that create value and those that do not and thus leading to adoption of public procurement audit in all areas that seek to help state corporations to have a competitive advantage over rivals and position themselves for future success (KPMG, 2012). 
International Journal of Supply Chain and Logistics

ISSSN 2520-4661 (Online)

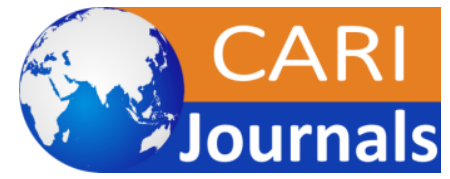

Vol. 4, Issue No.2, pp 104 -128, 2020

www.carijournals.org

In the recent past, a number of reports appearing in the print media reveal operational constraints in areas of operations management, fleet management, management information, and aspects which include uncertainty of customer demands, long supplier leads times, and inaccurate procurement needs estimation (World Bank, 2013). The systems audit for State law Office (SLO) report revealed losses of Kshs.18 Million through irregular manual procurements in financial year (FY) 2015/2016. Earlier, in the FY 2007/2015, SLO had lost Kshs.8 Million due to manual procurement related inefficiencies. This raises questions on the level of performance of SLO's procurement system as a state corporation. This situation is hampering sustained performance and service delivery (PPOA, 2014).

According to an annual Kenya Power customer satisfaction survey of 2012 and 2013, carried out by a contracted vendor, it is notable that the satisfaction percentage index has been fluctuating towards more and more dissatisfaction, that is, 69\% and 66\% respectively (Makau, 2014). On the other hand, Kenya Power faces a major challenge in controlling the overall sourcing costs because of the constant increase due lack of credible audit; this is evident by Kenya Power posting a decrease in profit prior to tax of Ksh.6 Billion compared to Ksh.8 Billion noted in the previous year (OECD, 2017).

A number of studies have been conducted on public procurement audit globally. For instance, Cousins (2015) conducted a survey on 21 state energy corporations in the UK and found out that though $92 \%$ claimed procurement audit seemed to have reduced transaction costs. The studies found that the investigated state energy corporations looked at procurement audit. This study was however, conducted in a developed country and not in Kenya. Several studies have been done locally; Kioko and Were (2014) did a study on factors affecting efficiency in public procurement audit in the private sector in Kenya. These studies however, did not look at effect of public procurement audit on the performance of state corporations. It is against this back drop that this study seeks to examine the effect of public procurement audit on the performance of state corporations in Kenya.

\subsection{Objectives of the Study}

i. To assess the effect of preparation and planning auditing on the performance of state corporations in Kenya.

ii. To establish the effect of information and publicity auditing on the performance of state corporations in Kenya.

iii. To determine the effect of evaluation of tenders auditing on the performance of state corporations in Kenya.

iv. To evaluate the effect of award and execution of contract auditing on the performance of state corporations in Kenya. 
International Journal of Supply Chain and Logistics

ISSSN 2520-4661 (Online)

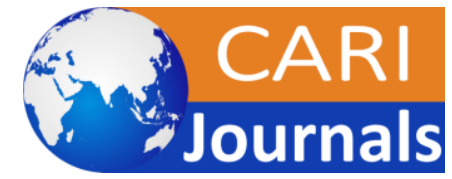

Vol. 4, Issue No.2, pp 104 -128, 2020

www.carijournals.org

\subsection{LITERATURE REVIEW}

\subsection{The Theory of Constraints}

Theory of constraints is an approach to the management of operations and it was developed by Goldratt (1981). It provides a supply chain management theory of how organizations should be run especially the when planning and preparing for procurement audit. There is always one constraint and the TOC uses a focusing process to identify the constraint and restructure the planning around it (Kotabe \& Murray, 2015). TOC emphasizes on the optimization of performance within a defined set of constraints of the existing process and it provides an action framework which combines the activities of the managers and the visible system elements (Hansen, Schaumburg-Muller \& Pottenger, 2015).

TOC views preparation and planning as systems consisting of resources, which are linked by the processes they perform. The goal of preparation and planning is to serve as the primary judge of success. Within that system, a constraint is defined as anything that limits preparation and planning from achieving higher performance relative to its purpose (Tummala, Phillips \& Johnson, 2016).

The theory of constraints defines a set of tools that change agents can use to manage constraints, thereby increasing profits. Most businesses can be viewed as a linked set of processes that transform inputs into saleable outputs (European Commission, 2017). TOC conceptually models this system as a chain, and advocates the familiar adage that a chain is only as strong as its weakest link (Busi \& McIvor, 2015). In the context of this study one of the variables of public procurement audit will show the linkage to one of the measures of success that are used to measure the performances of organizations in the public sector.

\subsection{Public Procurement Audit}

\subsubsection{Preparation and Planning Auditing and Performance of State Corporations}

Burke (2015) investigated the applicability of ISA 300: Planning an audit of financial statements and explained the purpose, methodology of audit planning. In her paper, she clarified the updated term of client acceptance, audit risk, client's business risk and analytical procedures. Zimbelman (2015) tested the cost and benefits of SAS No.82 by analyzing its impact on fraud detection, fraud risk management through audit planning decision. He found that audit planning helps to mitigate fraud risk by helping auditors identify fraud. Mugerwa (2016) studied the problem representation in audit planning by conducting an experimental study on 211 auditors from Big Eight audit companies. His experiment showed that managers and partners better form audit planning to do more efficient and effective work.

\subsubsection{Information and Publicity Auditing and Performance of State Corporations}

According to Gunasekeran (2015) at the national level public sector managers have to deal with a more competitive environment than has been the common practice in the past. The public is also demanding greater accountability and better service. The extensive dissemination of information and publicity has led to this competitiveness. Therefore, managing the risks associated with the complex competitive environment give rise to accountability problems, as the roles and 
responsibilities of the participants in the process are not clear. Good procurement holds its practitioners responsible for enforcing and obeying the rules (Richard, 2013). It makes them subject to challenge and to sanction, if appropriate, for neglecting or bending those rules. Accountability is at once a key inducement to individual and institutional probity, a key deterrent to collusion and corruption, and a key prerequisite for procurement credibility.

\subsubsection{Evaluation of Tenders Received Auditing and Performance of State Corporations}

Acquaye (2015) stated that after determining the lowest evaluated price, the tenderer's capability and resources available to carry out the work should be cross-checked. It is the review process carried out by the evaluation panel to ascertain whether the tenderer offered the lowest evaluated tender price has the capacity or resources to carry out the contract effectively. Again the document summarized and stated that the tender evaluation procedures involve two stages: assessment of information submitted which involves verification of information submitted or provided by the tenderer, in response to the tender document, the second stage is the tender evaluation report which captures all the tendering processes, from advertisement, tender submission and evaluation, in concise manner at the same time conveys, clearly, all the issues considered in arriving at the recommendation for the award of the contract.

\subsubsection{Award and Execution of Contract Auditing and Performance of State Corporations}

Kibogo and Mwangangi (2014) did a study on factors affecting contract execution in public procurement sector in Kenya: a case of Kenya Literature Bureau. The purpose of the study was to establish factors affecting contract management in public procurement sector. The specific objectives of the study were; to establish the effect of technology, management styles, relationship management, and employee competence on contract management in the public procurement sector in Kenya. The study found that information technology, management styles and employee competence influenced contract management in public procurement. The study adopted a descriptive research design which sought to establish factors associated with certain occurrences, outcomes, conditions or types of behavior. It also enabled the researcher to answer the questions of how, who, where, why, what and which. 


\subsection{Conceptual Framework}

Independent Variables

\begin{tabular}{|c|}
\hline $\begin{array}{l}\text { Preparation and Planning Auditing } \\
\text { - Object and Value } \\
\text { - Procurement Strategy } \\
\text { - Procedure and Schedule }\end{array}$ \\
\hline $\begin{array}{l}\text { Information and Publicity Auditing } \\
\text { - Drafting Tender Documentation } \\
\text { - Advertising } \\
\text { - Providing Clarifications }\end{array}$ \\
\hline $\begin{array}{l}\text { Evaluation of Tenders Received Auditing } \\
\text { - Reception of Tenders } \\
\text { - Technical Evaluation } \\
\text { - Evaluation of Financials }\end{array}$ \\
\hline $\begin{array}{l}\text { Award and Execution of Contract } \\
\text { Auditing } \\
\text { - Notifications of Award } \\
\text { - Implementation of Contract } \\
\text { - Completion and Handover }\end{array}$ \\
\hline
\end{tabular}

Figure 1: Conceptual Framework

\subsection{METHODOLOGY}

The study employed a descriptive research design, targeting heads of procurement in state corporations. As a rule of thumb when the population is below 200, a study does a census. The researcher preferred this method because it allowed an in-depth study of the subject. Data was collected using self-administered questionnaires. Pilot study was carried out to establish the validity and reliability of the research instruments. The instruments were designed appropriately according to the study objectives. The data collected was analyzed by use of descriptive and inferential statistics. The study used multiple regression and correlation analysis to show the relationship between the dependent variable and the independent variables. The data generated was keyed in and analyzed by use of Statistical Package of Social Sciences (SPSS) version 24 to generate information which was presented using charts, frequencies and percentages. 
International Journal of Supply Chain and Logistics

ISSSN 2520-4661 (Online)

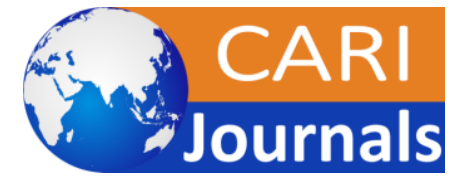

Vol. 4, Issue No.2, pp 104 -128, 2020

www.carijournals.org

\subsection{RESULTS FINDINGS}

\subsection{Introduction}

This chapter presents results arising from the analysis of data collected using questionnaires. I

\subsection{Response Rate}

A sample of respondents were interviewed using questionnaires that allowed the researcher to drop the questionnaire to the respondents and then collect them at a later date when they had filled the questionnaires. A total of 187 questionnares were distributed to heads of procurement. Out of the population covered, 150 were responsive respresenting a response rate of $80 \%$. This was above the $50 \%$ which is considered adequate in descriptive statistics according to (Mugenda \& Mugenda, 2012).

\section{Table 1: Response Rate of Respondents}

\begin{tabular}{lll}
\hline Response & Frequency & Percentage \\
\hline Actual Response & 150 & 80 \\
Non-Response & 37 & 20 \\
Total & 187 & $100 \%$ \\
\hline
\end{tabular}

\subsection{Pilot Study}

The cronbach's alpha was computed in terms of the average inter-correlations among the items measuring the concepts. The rule of thumb for cronbach's alpha is that the closer the alpha is to 1 the higher the reliability (Serekan, 2012). A value of at least 0.7 is recommended. Cronbach's alpha is the most commonly used coefficient of internal consistency and stability. Consistency indicated how well the items measuring the concepts hang together as a set. Cronbach's alpha was used to measure realibilty. This was done on the four objectives of the study. The higher the coefficient, the more reliable is the test.

Table 2: Reliability Results

\begin{tabular}{lcccc}
\hline Variable & No. of Items & Respondents & $\boldsymbol{\alpha}=$ Alpha & Comment \\
\hline Preparation and Planning Auditing & 9 & 19 & 0.893 & Reliable \\
Information and Publicity Auditing & 9 & 19 & 0.987 & Reliable \\
Evaluation of Tenders Auditing & 9 & 19 & 0.974 & Reliable \\
Award and Execution of Contract Auditing & 9 & 19 & 0.976 & Reliable \\
\hline
\end{tabular}


International Journal of Supply Chain and Logistics

ISSSN 2520-4661 (Online)

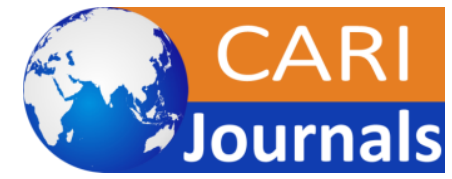

Vol. 4, Issue No.2, pp 104 -128, 2020

www.carijournals.org

\subsection{Demographics Information}

\subsubsection{Distribution of Respondents by Gender}

The study determined the gender distribution of the state corporations in average. The results summarized in the figure below. The result in figure 4.1 revealed that majority of the respondent $(54 \%)$ indicated that they were female, while only $(46 \%)$ of the respondent indicated that they were male.

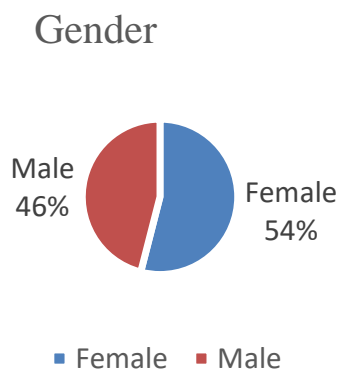

\section{Figure 2: Distribution of Respondents by Gender}

\subsubsection{Distribution of Respondents by Age}

The study determined the distribution of respondents by age. The results summarized in the table below. The results revealed that majority of the respondent (38\%) were between 41-50 years, (32\%) were 31- 40 years old, while (30\%) were above 50 years. The findings are in agreement with those of Hall (2014) who established that there are two natural age peaks of the early 30s and mid 40s which correlated to employee performance.

Table 3: Distribution of Respondents by Age

\begin{tabular}{lll}
\hline Years & Frequency & Percent \\
\hline $31-40$ Years & 48 & 32.0 \\
$41-50$ Years & 57 & 38.0 \\
50 Years and above & 45 & 30.0 \\
Total & $\mathbf{1 5 0}$ & $\mathbf{1 0 0 . 0 0}$ \\
\hline
\end{tabular}

\subsubsection{Distribution of Respondents by Level of Education}

The respondents were asked to state their highest level of education and the results revealed that majority of the respondent (68\%) indicated that their academic qualification was up to master's level. The result further revealed that $(48 \%)$ of the respondent indicated that their academic qualification was up to degree level. With majority responsdents having degree and above, it is expected that their level of understanding of performance of state corporations is good. This is an indication that the results obtained from respondents interviewed in the present study can be relied upon. These findings concur those of Hatry (2016) who established that majority of who run public procurement are highly educated and that there is evidence linking education and performance of state corporations. 
International Journal of Supply Chain and Logistics

ISSSN 2520-4661 (Online)

Vol. 4, Issue No.2, pp 104 -128, 2020

www.carijournals.org

Table 4: Distribution of Respondents by Level of Education

\begin{tabular}{lll}
\hline Education Level & Frequency & Percent \\
\hline Undergraduate & 48 & 32 \\
Post-Graduate & 102 & 68 \\
Total & $\mathbf{1 5 0}$ & $\mathbf{1 0 0}$ \\
\hline
\end{tabular}

\subsubsection{Distribution of Respondents by Length of Service}

The study determined the number of years the respondents had worked in their current office. The respondents were asked to indicate their work duration. The result revealed that majority of the respondents (37.3\%) indicated that their work duration was 9 and above years. The result also showed that $(26.0 \%)$ of the respondent indicated that their work duration was 3-5 years. The result also showed that $(36.7 \%)$ of the respondent indicated that their work duration was 6-8 years. The findings of the study are in tandem with literature review by Joiner (2012) who indicated that a duration and experience of employee helps him or her to have better knowledge and skills which contribute to performance.

Table 5: Distribution of Respondents by Length of Service

\begin{tabular}{lcc}
\hline Length of Service & Frequency & Percent \\
\hline 3-5 Years & 39 & 26.0 \\
6-8 Years & 55 & 36.7 \\
9 Years and above & 56 & 37.3 \\
Total & $\mathbf{1 5 0}$ & $\mathbf{1 0 0 . 0}$ \\
\hline
\end{tabular}

\subsection{Descriptive Statistics}

\subsubsection{Preparation and Planning Auditing}

The first objective of the study was to assess the effect of preparation and planning auditing on performance of state corporations in Kenya. The respondents were asked to indicate to what extent did preparation and planning auditing affect had on performance of state corporations in Kenya. Results indicated that majority of the respondents $25 \%$ agreed that it was to a very great extent, $27 \%$ said that it was to a great extent, $35 \%$ said it was moderate, while little extent and not all were at 5 and $8 \%$ respectively. 
International Journal of Supply Chain and Logistics

ISSSN 2520-4661 (Online)

Vol. 4, Issue No.2, pp 104 -128, 2020

$\underline{\text { www.carijournals.org }}$

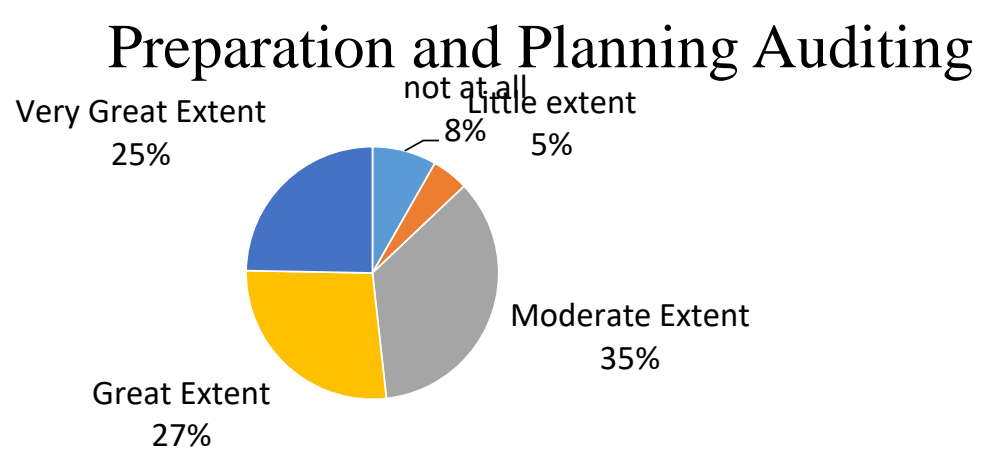

Figure 3: Preparation and Planning Auditing

The respondents were also asked to comment on statements regarding preparation and planning auditing on performance of state corporations in Kenya. The responses were rated on a Likert scale and the results presented in Table 3 below. It was rated on a 5 point Likert scale ranging from; 1 $=$ strongly disagree to $5=$ strongly agree. The scores of 'strongly disagree' and 'disagree' have been taken to represent a statement not agreed upon. The score of 'neutral' has been taken to represent a statement agreed upon. The score of 'agree' and 'strongly agree' have been taken to represent a statement highly agreed upon.

The respondents were asked to indicate the descriptive for preparation and planning auditing. The result revealed that majority of the respondent (62\%) agreed with the statement that Object and value auditing plays a great role in cost reductions. The result revealed that majority of the respondent $(72.7 \%)$ agreed with the statement that Procurement strategy plays a great role in cost reductions. The result also revealed that majority of the respondent (64.7\%) agreed with the statement that Procedure and schedule play a great role in cost reductions.

Further, the results revealed that majority of the respondent (100\%) agreed with the statement that Object and value auditing plays a great role in reducing lead time. Results also revealed that majority of the respondent $(98.7 \%)$ agreed with the statement that Procurement strategy plays a great role in reducing lead time. The result revealed that majority of the respondent $(99.3 \%)$ agreed with the statement that Procedure and schedule play a great role in reducing lead time.

Results further indicated that majority of the respondent (97.3\%) agreed with the statement that Object and value auditing plays a great role in improving quality of works and services. Results revealed that majority of the respondent (62.6\%) agreed with the statement that Procurement strategy plays a great role in improving quality of works and services. Finally, the results revealed that majority of the respondent $(97.3 \%)$ agreed with the statement that Procedure and schedule plays a great role in improving quality of works and services. The average for the statements on preparation and planning auditing was 4.25 . The results imply that an organization benefits greatly when preparation and planning auditing are embraced to reduce costs and work with the organization to streamline performance (Mackie, 2008). 
Table 6: Preparation and Planning Auditing

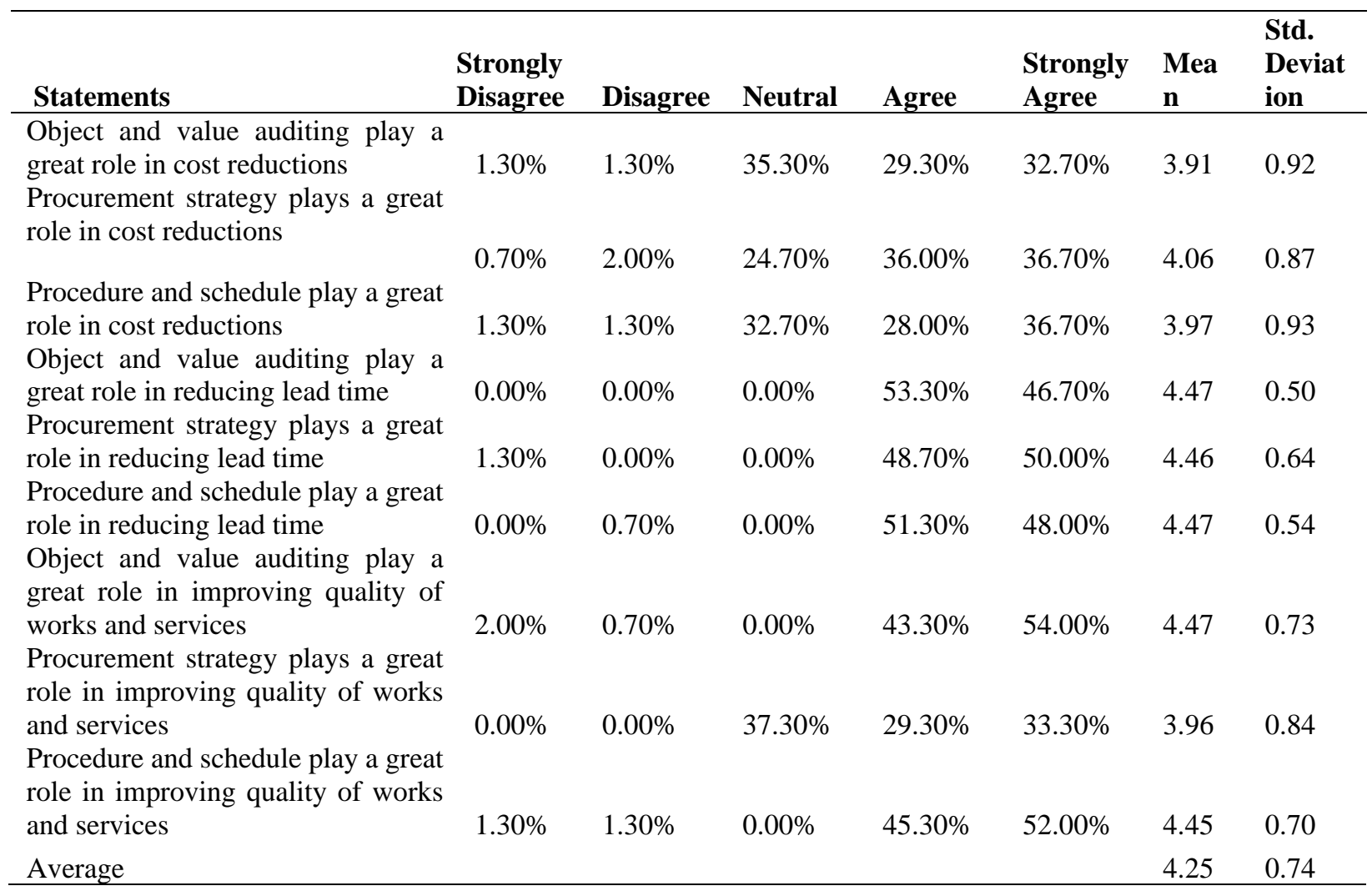

\subsubsection{Information and Publicity Auditing}

The second objective of the study was to establish the effect of information and publicity auditing on performance of state corporations in Kenya. The respondents were asked to indicate to what extent information and publicity auditing affected performance of state corporations in Kenya. Results indicated that majority of the respondents $31 \%$ agreed that it was to a very great extent, $36 \%$ said that it was to a great extent, $23 \%$ said it was moderate, while little extent and not all tied at $5 \%$.

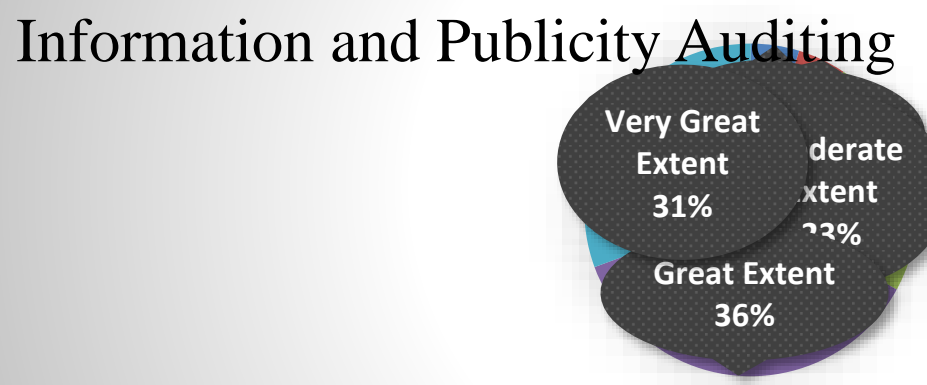

Figure 4. Information and Publicity Auditing 
The respondents were also asked to comment on statements regarding information and publicity auditing effect on performance of state corporations in Kenya. The respondents were asked to indicate descriptive responses for information and publicity auditing. The result revealed that majority of the respondents $(56.6 \%)$ indicated that they agreed with the statement that Drafting tender documentation plays a great role in cost reductions. The result further revealed that majority of the respondents (73.3\%) indicated that they agreed with the statement that Advertising plays a great role in cost reductions. The result revealed that majority of the respondents $(69.3 \%)$ indicated that they agreed with the statement that providing clarifications system play a great role in cost reductions.

The result further revealed that majority of the respondents (100\%) indicated that they agreed with the statement that drafting tender documentation plays a great role in reducing lead time. The result revealed that majority of the respondents (100\%) indicated that they agreed with the statement that Advertising plays a great role in reducing lead time. The result further revealed that majority of the respondents $(40.7 \%)$ indicated that they agreed with the statement that Providing clarifications system play a great role in reducing lead time.

The result revealed that majority of the respondents (46.6\%) indicated that they agreed with the statement that Drafting tender documentation plays a great role in improving quality of works and services. The result further revealed that majority of the respondents $(48.7 \%)$ indicated that they agreed with the statement that Advertising plays a great role in improving quality of works and services. The result revealed that majority of the respondents $(52.6 \%)$ indicated that they agreed with the statement that Providing clarifications system plays a great role in improving quality of works and services.

The average for the statements on information and publicity auditing was 3.8. The results imply that an organization benefits greatly when information and publicity auditing is embraced to reduce costs, introduce systems designed to address the organization's needs, and work with the organization to streamline performance (Lazear, 2010). 
Table 7: Information and Publicity Auditing

\begin{tabular}{|c|c|c|c|c|c|c|c|}
\hline Statements & $\begin{array}{l}\text { Strongly } \\
\text { Disagree }\end{array}$ & $\begin{array}{l}\text { Disagre } \\
\text { e }\end{array}$ & Neutral & Agree & $\begin{array}{l}\text { Strongl } \\
\text { y Agree }\end{array}$ & $\begin{array}{l}\text { Mea } \\
\text { n }\end{array}$ & $\begin{array}{l}\text { Std. } \\
\text { Devia } \\
\text { tion }\end{array}$ \\
\hline $\begin{array}{l}\text { Drafting tender documentation plays a } \\
\text { great role in cost reductions }\end{array}$ & $0.0 \%$ & $0.0 \%$ & $43.3 \%$ & $21.3 \%$ & $35.3 \%$ & 3.9 & 0.9 \\
\hline $\begin{array}{l}\text { Advertising plays a great role in cost } \\
\text { reductions }\end{array}$ & $0.0 \%$ & $0.0 \%$ & $26.7 \%$ & $36.0 \%$ & $37.3 \%$ & 4.1 & 0.8 \\
\hline $\begin{array}{l}\text { Providing clarifications system play a } \\
\text { great role in cost reductions }\end{array}$ & $0.0 \%$ & $0.0 \%$ & $30.7 \%$ & $37.3 \%$ & $32.0 \%$ & 4.0 & 0.8 \\
\hline $\begin{array}{l}\text { Drafting tender documentation plays a } \\
\text { great role in reducing lead time }\end{array}$ & $0.0 \%$ & $0.0 \%$ & $0.0 \%$ & $45.3 \%$ & $54.7 \%$ & 4.6 & 0.5 \\
\hline $\begin{array}{l}\text { Advertising plays a great role in } \\
\text { reducing lead time }\end{array}$ & $0.0 \%$ & $0.0 \%$ & $0.0 \%$ & $50.0 \%$ & $50.0 \%$ & 4.5 & 0.5 \\
\hline $\begin{array}{l}\text { Providing clarifications system play a } \\
\text { great role in reducing lead time }\end{array}$ & $22.7 \%$ & $18.0 \%$ & $21.3 \%$ & $18.7 \%$ & $19.3 \%$ & 2.9 & 1.4 \\
\hline $\begin{array}{l}\text { Drafting tender documentation plays a } \\
\text { great role in improving quality of works } \\
\text { and services }\end{array}$ & $15.3 \%$ & $18.0 \%$ & $20.0 \%$ & $21.3 \%$ & $25.3 \%$ & 3.2 & 1.4 \\
\hline $\begin{array}{l}\text { Advertising plays a great role in } \\
\text { improving quality of works and services }\end{array}$ & $0.0 \%$ & $22.0 \%$ & $29.3 \%$ & $28.7 \%$ & $20.0 \%$ & 3.5 & 1.0 \\
\hline $\begin{array}{l}\text { Providing clarifications system plays a } \\
\text { great role in improving quality of works } \\
\text { and services }\end{array}$ & $0.0 \%$ & $26.0 \%$ & $21.3 \%$ & $21.3 \%$ & $31.3 \%$ & 3.6 & 1.2 \\
\hline Average & & & & & & 3.8 & 0.9 \\
\hline
\end{tabular}

\subsubsection{Evaluation of Tenders Received Auditing}

There was also need to establish effect of evaluation of tenders received auditing on performance of state corporations in Kenya as the third objective. The respondents were asked to comment on extent of evaluation of tenders received auditing on performance of state corporations in Kenya as the third objective. Results indicated that majority of the respondents $47 \%$ agreed that it was to a very great extent, $45 \%$ said that it was to a great extent, $2 \%$ said it was moderate; little extent was $2 \%$ and not all at $4 \%$.

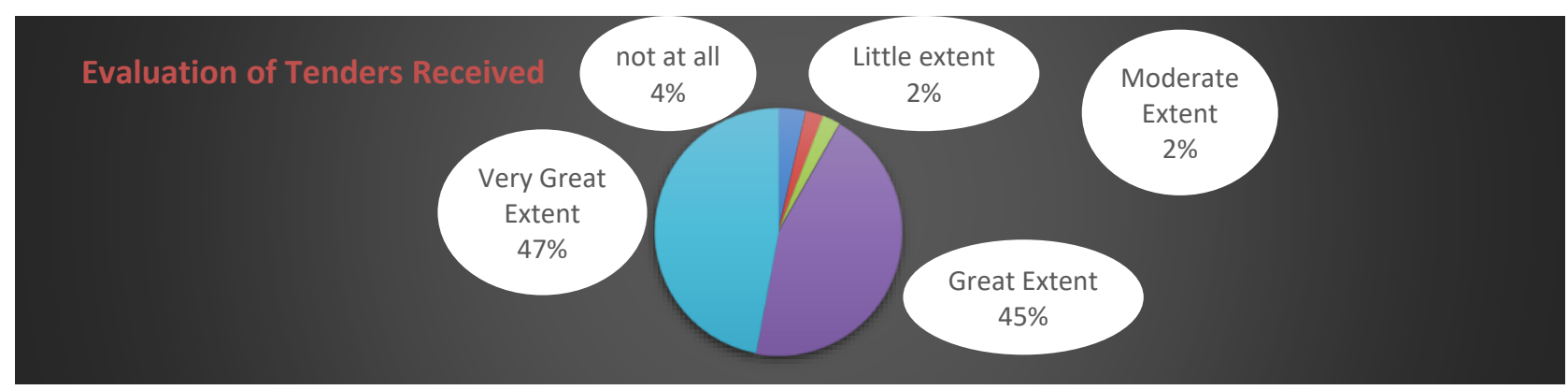

\section{Figure 5: Evaluation of Tenders Received Auditing}

The respondents were asked to indicate their levels of agreement on statements regarding evaluation of tenders received auditing. The result revealed that majority of the respondent $(62.7 \%)$ 
agreed with the statement that Reception of tenders plays a great role in cost reductions. The result further revealed that majority of the respondent (71.4\%) agreed with the statement that Technical evaluation plays a great role in cost reductions. The result revealed that majority of the respondent $(62 \%)$ agreed with the statement that Evaluation of financials play a great role in cost reductions.

The result further revealed that majority of the respondent $(63.4 \%)$ agreed with the statement that Reception of tenders plays a great role in reducing lead time. The result revealed that majority of the respondent $(70 \%)$ agreed with the statement that Technical evaluation plays a great role in reducing lead time. The result further revealed that majority of the respondent $(69.4 \%)$ agreed with the statement that Evaluation of financials play a great role in reducing lead time.

The result revealed that majority of the respondent $(43.4 \%)$ disagreed with the statement that Reception of tenders plays a great role in improving quality of works and services. The result further revealed that majority of the respondent (100\%) agreed with the statement that Technical evaluation plays a great role in improving quality of works and services. The result revealed that majority of the respondent $(100 \%)$ agreed with the statement that Evaluation of financials plays a great role in improving quality of works and services. The average for the statements on evaluation of tenders received auditing was 3.79. The results imply that an organization benefits greatly when evaluation of tenders received auditing is embraced to reduce costs, to streamline performance (Larry, 2013). 
International Journal of Supply Chain and Logistics

ISSSN 2520-4661 (Online)

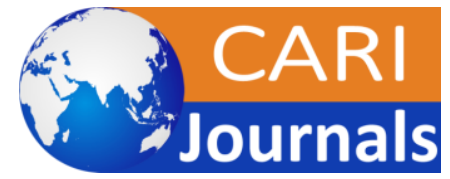

Vol. 4, Issue No.2, pp 104 -128, 2020

www.carijournals.org

Table 8: Evaluation of Tenders Received Auditing

\begin{tabular}{llllllll}
\hline & $\begin{array}{l}\text { Strongly } \\
\text { Disagree }\end{array}$ & $\begin{array}{l}\text { Disagre } \\
\text { Statements }\end{array}$ & Neutral & Agree & $\begin{array}{l}\text { Strongly } \\
\text { Agree }\end{array}$ & Mean & $\begin{array}{l}\text { Std. } \\
\text { Deviation }\end{array}$ \\
\hline $\begin{array}{l}\text { Reception of tenders plays a } \\
\text { great role in cost reductions }\end{array}$ & $0.00 \%$ & $0.00 \%$ & $37.30 \%$ & $30.70 \%$ & $32.00 \%$ & 4.11 & 0.796 \\
$\begin{array}{l}\text { Technical evaluation plays a } \\
\text { great role in cost reductions }\end{array}$ & $0.00 \%$ & $0.00 \%$ & $28.70 \%$ & $34.70 \%$ & $36.70 \%$ & 4.01 & 0.794 \\
$\begin{array}{l}\text { Evaluation of financials play a } \\
\text { great role in cost reductions }\end{array}$ & $0.00 \%$ & $0.00 \%$ & $38.00 \%$ & $33.30 \%$ & $28.70 \%$ & 4.55 & 0.499 \\
$\begin{array}{l}\text { Reception of tenders plays a } \\
\text { great role in reducing lead time }\end{array}$ & $0.00 \%$ & $0.00 \%$ & $36.70 \%$ & $36.70 \%$ & $26.70 \%$ & 4.5 & 0.502 \\
$\begin{array}{l}\text { Technical evaluation plays a } \\
\text { great role in reducing lead time }\end{array}$ & $0.00 \%$ & $0.00 \%$ & $30.00 \%$ & $42.00 \%$ & $28.00 \%$ & 2.94 & 1.434 \\
$\begin{array}{l}\text { Evaluation of financials play a } \\
\text { great role in reducing lead time }\end{array}$ & $0.00 \%$ & $0.00 \%$ & $30.70 \%$ & $38.70 \%$ & $30.70 \%$ & 3.23 & 1.407 \\
$\begin{array}{l}\text { Reception of tenders plays a } \\
\text { great role in improving quality of } \\
\text { works and services }\end{array}$ & $20.70 \%$ & $22.7 \%$ & $21.30 \%$ & $20.00 \%$ & $15.30 \%$ & 3.47 & 1.047 \\
$\begin{array}{l}\text { Technical evaluation plays a } \\
\text { great role in improving quality of } \\
\text { works and services }\end{array}$ & $0.00 \%$ & $0.00 \%$ & $0.00 \%$ & $48.00 \%$ & $52.00 \%$ & 3.58 & 1.183 \\
$\begin{array}{l}\text { Evaluation of financials plays a } \\
\text { great role in improving quality of } \\
\text { works and services } \\
\text { Average }\end{array}$ & $0.00 \%$ & $0.00 \%$ & $0.00 \%$ & $50.00 \%$ & $50.00 \%$ & & \\
\hline
\end{tabular}

\subsubsection{Award and Execution of Contract Auditing}

There was also need to establish the effect of award and execution of contract auditing on performance of state corporations in Kenya. The respondents were also asked to comment on statements regarding award and execution of contract auditing on performance of state corporations in Kenya. Results also showed that $3 \%$ of respondents indicated to very great extent, great extent was at $12 \%$, moderate extent was $3 \%$, while little extent was at $27 \%$ and not at all was at $21 \%$. 


\section{Award and Execution of Contract Auditing}

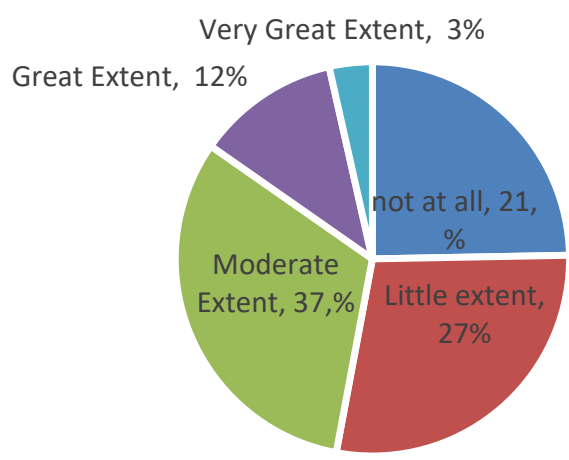

\section{Figure 6: Award and Execution of Contract Auditing}

The respondents were asked to indicate the descriptive for award and execution of contract auditing. The result revealed that majority of the respondent (100\%) agreed with the statement that Notifications of award plays a great role in cost reductions. The result further revealed that majority of the respondent $(100 \%)$ agreed with the statement that Implementation of contract plays a great role in cost reductions. The result revealed that majority of the respondent (95.4\%) agreed with the statement that Completion and handover play a great role in cost reductions.

The result further revealed that majority of the respondent (96\%) agreed with the statement that Notifications of award plays a great role in reducing lead time. The result revealed that majority of the respondent $(100 \%)$ agreed with the statement that Implementation of contract plays a great role in reducing lead time. The result further revealed that majority of the respondent $(100 \%)$ agreed with the statement that Completion and handover play a great role in reducing lead time.

The result further revealed that majority of the respondent (95.3\%) agreed with the statement that Notifications of award plays a great role in improving quality of works and services. The result further revealed that majority of the respondent (100\%) agreed with the statement that Implementation of contract plays a great role in improving quality of works and services. The result further revealed that majority of the respondent (100\%) agreed with the statement that Completion and handover plays a great role in improving quality of works and services.

The average for the statements on award and execution of contract auditing was 3.79. The results imply that an organization benefits greatly when reliable award and execution of contract auditing are embraced to reduce costs, introduce systems designed to address the organization's needs, and work with the organization to streamline performance (Jolley, 2013). 
International Journal of Supply Chain and Logistics

ISSSN 2520-4661 (Online)

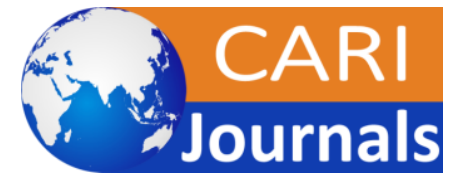

Vol. 4, Issue No.2, pp 104 -128, 2020

www.carijournals.org

Table 9: Award and Execution of Contract Auditing

\begin{tabular}{|c|c|c|c|c|c|c|c|}
\hline Statements & $\begin{array}{l}\text { Strongly } \\
\text { Disagree }\end{array}$ & Disagree & Neutral & Agree & $\begin{array}{l}\text { Strongly } \\
\text { Agree }\end{array}$ & Mean & $\begin{array}{l}\text { Std. } \\
\text { Deviatio } \\
\text { n }\end{array}$ \\
\hline $\begin{array}{l}\text { Notifications of award plays a } \\
\text { great role in cost reductions }\end{array}$ & $0.00 \%$ & $0.00 \%$ & $0.00 \%$ & $54.00 \%$ & $46.00 \%$ & 4.11 & 0.796 \\
\hline $\begin{array}{l}\text { Implementation of contract plays } \\
\text { a great role in cost reductions }\end{array}$ & $0.00 \%$ & $0.00 \%$ & $0.00 \%$ & $48.70 \%$ & $51.30 \%$ & 4.01 & 0.794 \\
\hline $\begin{array}{l}\text { Completion and handover play a } \\
\text { great role in cost reductions }\end{array}$ & $0.00 \%$ & $1.30 \%$ & $3.30 \%$ & $40.70 \%$ & $54.70 \%$ & 4.55 & 0.499 \\
\hline $\begin{array}{l}\text { Notifications of award plays a } \\
\text { great role in reducing lead time } \\
\text { Implementation of contract plays }\end{array}$ & $1.30 \%$ & $1.30 \%$ & $1.30 \%$ & $56.70 \%$ & $39.30 \%$ & 4.5 & 0.502 \\
\hline $\begin{array}{l}\text { a great role in reducing lead time } \\
\text { Completion and handover play a }\end{array}$ & $0.00 \%$ & $0.00 \%$ & $0.00 \%$ & $47.30 \%$ & $52.70 \%$ & 2.94 & 1.434 \\
\hline $\begin{array}{l}\text { great role in reducing lead time } \\
\text { Notifications of award plays a }\end{array}$ & $0.00 \%$ & $0.00 \%$ & $0.00 \%$ & $50.00 \%$ & $50.00 \%$ & 3.23 & 1.407 \\
\hline $\begin{array}{l}\text { great role in improving quality of } \\
\text { works and services } \\
\text { Implementation of contract plays }\end{array}$ & $0.70 \%$ & $1.30 \%$ & $2.70 \%$ & $44.00 \%$ & $51.30 \%$ & 3.47 & 1.047 \\
\hline $\begin{array}{l}\text { a great role in improving quality } \\
\text { of works and services }\end{array}$ & $0.00 \%$ & $0.00 \%$ & $0.00 \%$ & $52.70 \%$ & $47.30 \%$ & 3.58 & 1.183 \\
\hline $\begin{array}{l}\text { Completion and handover play a } \\
\text { great role in improving quality of } \\
\text { works and services }\end{array}$ & $0.00 \%$ & $0.00 \%$ & $0.00 \%$ & $50.70 \%$ & $49.30 \%$ & 3.24 & 1.23 \\
\hline Average & & & & & & 3.79 & 0.957 \\
\hline
\end{tabular}


International Journal of Supply Chain and Logistics

ISSSN 2520-4661 (Online)

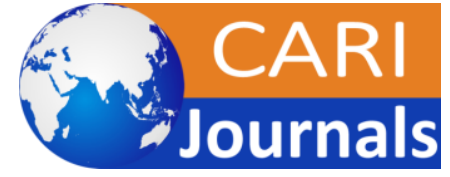

Vol. 4, Issue No.2, pp 104 -128, 2020

www.carijournals.org

\subsection{Correlation Analysis}

Correlation analysis was used to determine both the significance and degree of association of the variables and also predict the level of variation in the dependent variable caused by the independent variables.

Table 10: Summary of Pearson's Correlations

\begin{tabular}{|c|c|c|c|c|c|c|}
\hline Correlations & & $\begin{array}{l}\text { Preparation } \\
\text { and Planning } \\
\text { Auditing }\end{array}$ & $\begin{array}{l}\text { Informati } \\
\text { on and } \\
\text { Publicity } \\
\text { Auditing }\end{array}$ & $\begin{array}{l}\text { Evaluati } \\
\text { on of } \\
\text { Tenders } \\
\text { Received } \\
\text { Auditing }\end{array}$ & $\begin{array}{l}\text { Award and } \\
\text { Execution } \\
\text { of Contract } \\
\text { Auditing }\end{array}$ & $\begin{array}{l}\text { Performanc } \\
\mathrm{e} \text { of State } \\
\text { Corporation } \\
\mathrm{s}\end{array}$ \\
\hline Preparation & Pearson & & & & & \\
\hline Planning Auditing & $\begin{array}{l}\text { Correlation } \\
\text { Sig. (2-tailed) }\end{array}$ & 1 & & & & \\
\hline $\begin{array}{ll}\text { Information } & \text { and } \\
\text { Publicity Auditing } & \end{array}$ & $\begin{array}{l}\text { Pearson } \\
\text { Correlation }\end{array}$ & $.598 * *$ & 1 & & & \\
\hline $\begin{array}{l}\text { Evaluation of Tenders } \\
\text { Received Auditing }\end{array}$ & $\begin{array}{l}\text { Sig. (2-tailed) } \\
\text { Pearson } \\
\text { Correlation }\end{array}$ & $\begin{array}{l}0.000 \\
.589 * *\end{array}$ & $.469 * *$ & 1 & & \\
\hline $\begin{array}{l}\text { Award and Execution of } \\
\text { Contract Auditing }\end{array}$ & $\begin{array}{l}\text { Sig. (2-tailed) } \\
\text { Pearson } \\
\text { Correlation }\end{array}$ & $\begin{array}{l}0.000 \\
.588 * *\end{array}$ & $.780 * *$ & $.532 * *$ & 1 & \\
\hline $\begin{array}{l}\text { Performance of State } \\
\text { Corporations }\end{array}$ & $\begin{array}{l}\text { Sig. (2-tailed) } \\
\text { Pearson } \\
\text { Correlation }\end{array}$ & 0.000 & 0.000 & 0.000 & $.696 * *$ & 1 \\
\hline & Sig. (2-tailed) & 0.000 & 0.000 & 0.000 & 0.000 & \\
\hline
\end{tabular}

** Correlation is significant at the 0.05 Level (2-Tailed).

The correlation summary shown in Table 10 indicates that the associations between each of the independent variables and the dependent variable were all significant at the $95 \%$ confidence level. The correlation analysis to determine the relationship between preparation and planning auditing and performance of state corporations in Kenya, Pearson correlation coefficient computed and tested at 5\% significance level. The results indicate that there is a positive relationship $(\mathrm{r}=0.806)$ between preparation and planning auditing and performance of state corporations in Kenya. In addition, the researcher found the relationship to be statistically significant at $5 \%$ level $(\mathrm{p}=0.000$, $<0.05)$.

The correlation analysis to determine the relationship between information and publicity auditing and performance of state corporations in Kenya, Pearson correlation coefficient computed and tested at 5\% significance level. The results indicate that there is a positive relationship $(\mathrm{r}=0.684)$ between information and publicity auditing and performance of state corporations in Kenya. In addition, the researcher found the relationship to be statistically significant at $5 \%$ level $(\mathrm{p}=0.000$, $<0.05)$.

The correlation analysis to determine the relationship between of evaluation of tenders received auditing on performance of state corporations in Kenya, Pearson correlation coefficient computed 
International Journal of Supply Chain and Logistics

ISSSN 2520-4661 (Online)

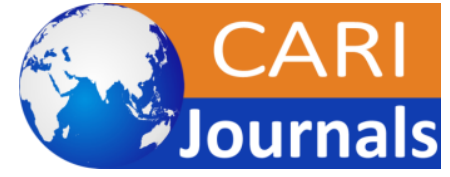

Vol. 4, Issue No.2, pp $104-128,2020$

www.carijournals.org

and tested at $5 \%$ significance level. The results indicate that there is a positive relationship $(r=0.680)$ between of evaluation of tenders received auditing and performance of state corporations in Kenya. In addition, the researcher found the relationship to be statistically significant at $5 \%$ level $(\mathrm{p}=0.000,<0.05)$.

The correlation analysis to determine the relationship between award and execution of contract auditing and performance of state corporations in Kenya, Pearson correlation coefficient computed and tested at 5\% significance level. The results indicate that there is a positive relationship $(\mathrm{r}=0.696)$ between award and execution of contract auditing and performance of state corporations in Kenya. In addition, the researcher found the relationship to be statistically significant at $5 \%$ level $(\mathrm{p}=0.000,<0.05)$. Hence, it is evident that all the independent variables could explain the changes in the performance of state corporations in Kenya, on the basis of the correlation analysis.

\subsection{Regression Analysis}

In this study multivariate regression analysis was used to determine the significance of the relationship between the dependent variable and all the independent variables pooled together. Regression analysis was conducted to find the proportion in the dependent variable (performance of state corporations in Kenya) which can be predicted from the independent variables (preparation and planning auditing, information and publicity auditing, evaluation of tenders auditing and award and execution of contract auditing).

Table 11 presents the regression coefficient of independent variables against dependent variable. The results of regression analysis revealed there is a significant positive relationship between dependent variable and the independent variable. The independent variables reported $\mathrm{R}$ value of 0.876 indicating that there is perfect relationship between dependent variable and independent variables. R square value of 0.768 means that $76.8 \%$ of the corresponding variation in performance of state corporations in Kenya can be explained or predicted by (preparation and planning auditing, information and publicity auditing, evaluation of tenders auditing and award and execution of contract auditing) which indicated that the model fitted the study data. The results of regression analysis revealed that there was a significant positive relationship between dependent variable and independent variable at $(\beta=0.761), p=0.000<0.05)$.

Table 11: Model Summary

\begin{tabular}{lllll}
\hline Model & R & R Square & Adjusted R Square & $\begin{array}{l}\text { Std. Error of the } \\
\text { Estimate }\end{array}$ \\
\hline 1 & $.876 \mathrm{a}$ & .768 & .761 & .1148 \\
\hline
\end{tabular}

Predictors: (constant), Preparation and Planning Auditing, Information and Publicity Auditing, Evaluation of Tenders Received Auditing, Award and Execution of Contract Auditing.

Dependent Variable: Performance of State Corporations. 
International Journal of Supply Chain and Logistics

ISSSN 2520-4661 (Online)

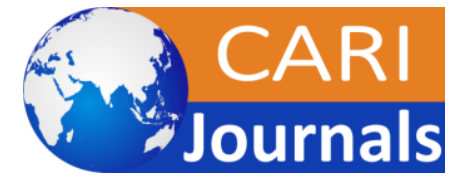

Vol. 4, Issue No.2, pp $104-128,2020$

www.carijournals.org

Table 12: ANOVA

\begin{tabular}{|c|c|c|c|c|c|c|}
\hline Model & & $\begin{array}{l}\text { Sum } \\
\text { Squares }\end{array}$ & of $\mathrm{df}$ & Mean Square & $\mathbf{F}$ & Sig. \\
\hline \multirow[t]{2}{*}{1} & Regression & 6.329 & 4 & 1.582 & 119.907 & $.000^{\mathrm{b}}$ \\
\hline & $\begin{array}{c}\text { Residual } \\
\text { Total }\end{array}$ & $\begin{array}{l}1.913 \\
8.243\end{array}$ & $\begin{array}{l}145 \\
149\end{array}$ & 0.013 & & \\
\hline
\end{tabular}

The significance value is 0.000 which is less than 0.05 thus the model is statistically significance in predicting how preparation and planning auditing, information and publicity auditing, evaluation of tenders received auditing and award and execution of contract auditing affect performance of state corporations in Kenya. The F critical at 5\% level of significance was 86.80 . Since F calculated which can be noted from the ANOVA table above is 119.907 which is greater than the F critical (value=86.80), this shows that the overall model was significant.

The study therefore, establishes that; preparation and planning auditing, information and publicity auditing, evaluation of tenders received auditing and award and execution of contract auditing affect performance of state corporations in Kenya. These results agree with Gianakis (2012) results which indicated a positive and significant effect of public procurement audit on performance of state corporations.

Table 13: Coefficients of Determination

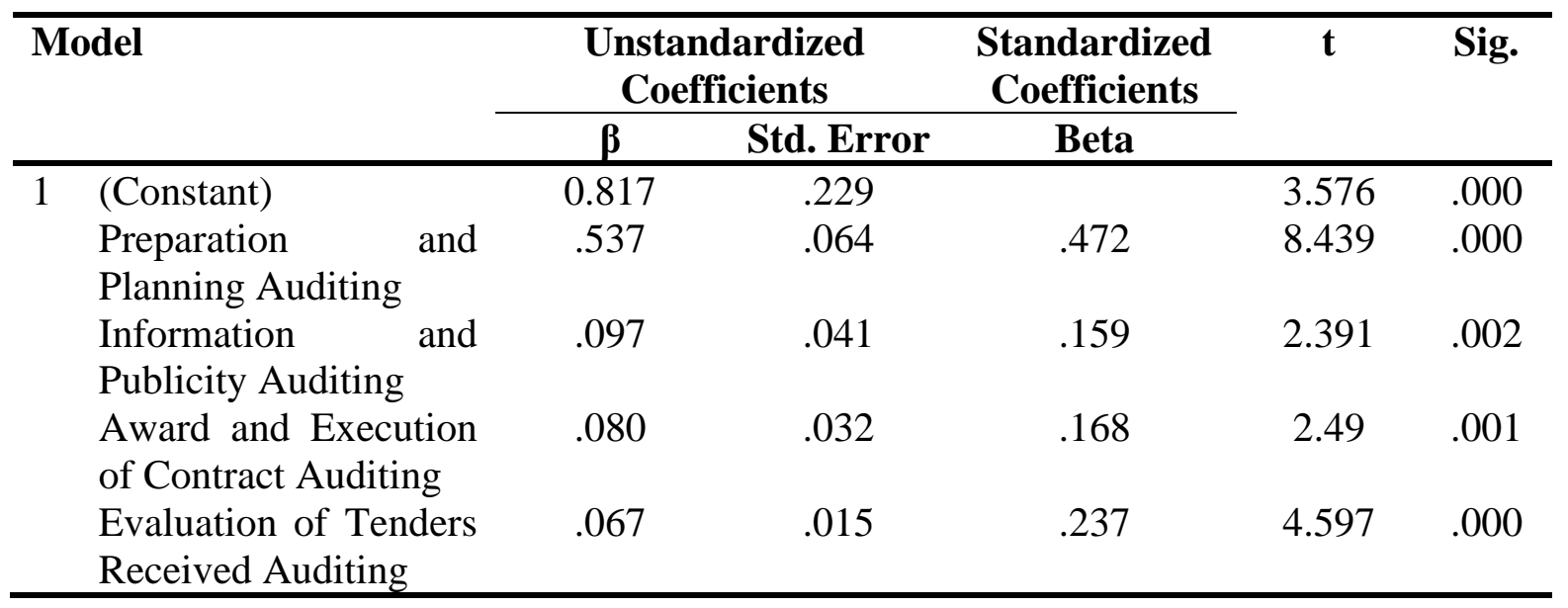

The research used a multiple regression model

$$
Y=\beta_{0}+\beta_{1} X_{1}+\beta_{2} X_{2}+\beta_{3} X_{3}+\beta_{4} X_{4}+\varepsilon
$$

Where $\mathrm{Y}=$ Performance of State Corporations in Kenya

$$
\begin{aligned}
& \beta_{0}=\text { Constant } \\
& X_{1}=\text { Preparation and Planning Auditing } \\
& X_{2}=\text { Information and Publicity Auditing }
\end{aligned}
$$


International Journal of Supply Chain and Logistics

ISSSN 2520-4661 (Online)

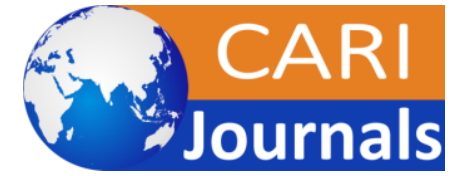

Vol. 4, Issue No.2, pp 104 -128, 2020

www.carijournals.org

$$
\begin{aligned}
& X_{3}=\text { Evaluation of Tenders Received Auditing } \\
& X_{4}=\text { Award and Execution of Contract Auditing } \\
& \varepsilon=\text { Error Term at } 95 \% \text { Confidence Level. }
\end{aligned}
$$

The regression equation was;

$$
\mathrm{Y}=0.817+0.537 \mathrm{X}_{1}+0.097 \mathrm{X}_{2}+0.08 \mathrm{X}_{3}+0.067 \mathrm{X}_{4}
$$

The regression equation above has established that taking all factors into account (preparation and planning auditing, information and publicity auditing, evaluation of tenders received auditing and award and execution of contract auditing) constant at zero, performance of state corporations in Kenya was an index of 0.817 . The findings presented also shows that taking all other independent variables at zero, a unit increase in preparation and planning auditing will lead to a 0.537 increase in performance of state corporations in Kenya. The P-value was 0.000 which is less 0.05 and thus the relationship was significant.

The study also found that a unit increase in information and publicity auditing will lead to a 0.097 increase in performance of state corporations in Kenya. The P-value was 0.002 and thus the relationship was significant. In addition, the study found that a unit increase in evaluation of tenders received auditing will lead to a 0.067 increase in the performance of state corporations in Kenya. The P-value was 0.000 and thus the relationship was significant.

Lastly, the study found that a unit increase in award and execution of contract auditing will lead to a 0.08 increase in the performance of state corporations in Kenya. The P-value was 0.001 and hence the relationship was significant since the $p$-value was lower than 0.05 . The findings of the study show that, preparation and planning auditing contributed most to the performance of state corporations in Kenya.

\subsection{SUMMARY, CONCLUSION AND RECOMMENDATIONS}

\subsection{Summary of the Findings}

The regression equation above has established that taking all factors into account (preparation and planning auditing, information and publicity auditing, evaluation of tenders received auditing and award and execution of contract auditing) constant at zero, performance of state corporations in Kenya was an index of 0.817 . The findings presented also shows that taking all other independent variables at zero, a unit increase in preparation and planning auditing will lead to a 0.537 increase in performance of state corporations in Kenya. The P-value was 0.000 which is less 0.05 and thus the relationship was significant.

The study also found that a unit increase in information and publicity auditing will lead to a 0.097 increase in performance of state corporations in Kenya. The P-value was 0.002 and thus the relationship was significant. In addition, the study found that a unit increase in evaluation of 
International Journal of Supply Chain and Logistics

ISSSN 2520-4661 (Online)

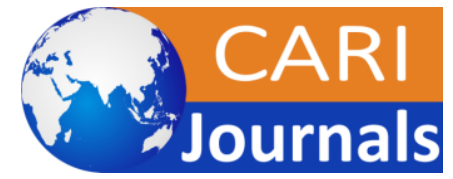

Vol. 4, Issue No.2, pp 104 -128, 2020

www.carijournals.org

tenders received auditing will lead to a 0.067 increase in the performance of state corporations in Kenya. The P-value was 0.000 and thus the relationship was significant.

Lastly, the study found that a unit increase in award and execution of contract auditing will lead to a 0.08 increase in the performance of state corporations in Kenya. The P-value was 0.001 and hence the relationship was significant since the p-value was lower than 0.05 . The findings of the study show that, preparation and planning auditing contributed most to the performance of state corporations in Kenya.

\subsection{Conclusion}

The findings of the study concluded that preparation and planning auditing, information and publicity auditing, evaluation of received tenders auditing, award and execution of contract auditing have a positive relationship with performance of state corporations in Kenya

\subsection{Recommendations}

The study recommended that public institutions should embrace public procurement audit so as to improve performance and further researches should to be carried out in other public institutions to find out if the same results can be obtained.

\section{REFERENCES}

Aberdeen Group (2014). Supply chain inventory strategies benchmark report: how inventory misconceptions and inertia are damaging companies' service levels and financial results, Aberdeen Group.

Donald, C. (2016). Synthesizing Research; A guide for Literature Reviews (3rd edn) Sage: Thousand Oaks

Dunn, S.D. (2017). Statistics and Data analysis for the Behavioural Science: Mc Graw Hill

Isaac, S., \& Michael, W.B. (2017). Handbook in Research and Evaluation for Education and the Behavioral Sciences. Macdonald and Evans, Ohio. U.S.A

John, G., \& Johnson, P. (2012). Research methods for Managers, 4th Edition. Sage Publications: London.

Kasomo, D. (2007). Research Methods in Humanities and Education, Eldoret; Zapf Chancery.

Kingori, N. (2012). Factors Affecting Procurement Manual Adoption by Secondary Schools in Kenya, Msc research project Jomo Kenyatta University of Science and Technology

Kothari, C.R. (2015). Research Methodology; Methods \& Techniques (2 ${ }^{\text {nd }}$ ed.). New Delhi; New Age International Press Limited.

KPMG (2015). Governance Survey. Nairobi: KPMG.

Lysons, K., \& Gullingham, M. (2013). Purchasing and Supply Chain Management, (6th Ed). London: Pearsons Hall. 
International Journal of Supply Chain and Logistics

ISSSN 2520-4661 (Online)

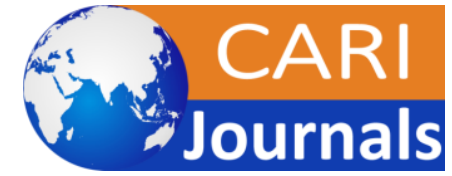

Vol. 4, Issue No.2, pp 104 -128, 2020

www.carijournals.org

Mugenda, A., \& Mugenda, O. (2015). Research Methods: 1st Edition, Published by ACTS, Nairobi, Kenya.

Abere, D.O., \& Muturi, W. (2015). Factors affecting compliance with the public procurement and disposal regulations. International Journal of Economics, Commerce and Management, 3(1), 1061-1090.

Barsemoi, H., Mwangagi, P., \& Asienyo, B.O., (2014). Factors Influencing Procurement Performance in Private Sector in Kenya, International Journal of Innovation and Applied Studies, 9 (2), 632-641.

Chogo, K. C., Ibua, M., Banafa, A., \& Adem, A., (2016). Factors Affecting Procurement Law Compliance in Public Secondary Schools in Kenya (A Case Study of Public Secondary Schools in Kwale County), Imperial Journal of Interdisciplinary Research, 2(11), 15921600 .

Cooper, D. R., \& Schindler, P. S. (2014). Business Research Methods (12th Edition). New York: McGraw- Hill/Irwin

Davis, J.M. (2014). Procurement Practices Influencing Service Delivery: A Case of Kenya Power, European Journal of Logistics Purchasing and Supply chain performance, 2(3), 79-137.

Inzofu, K.M. (2016). Challenges to implementation of electronic procurement in the construction sector (Master's Thesis), KCA University, Kenya.

Kagai, L. (2013). Impact of electronic procurement on the performance of private universities in Nairobi County (master's thesis), University of Nairobi, Kenya.

Kangogo, J., \& Kiptoo, E.J. (2013). Factors Affecting Ethical Standards in Public Procurement in Kenya, International Journal of Management Science, 1(3), 90-99.

Khadija, R., \& Kibet, Y. (2015). Factors affecting implementation of public procurement procedures and practices in Elgeyo-Marakwet County. International Academic Journal of Procurement and Supply chain performance, 1 (5), 121-135

Kiama, G.P., (2014). Factors Affecting Compliance of Public Procurement Act in SACCO Societies in Kenya, International Journal of Academic Research in Business and Social Sciences, 4(2), 169-194.

Marco, M. (2015). Effectiveness of performance appraisal practices in public secondary schools in Tanzania. A case of public secondary schools in Dodoma Municipal Council, (master's thesis), University of Dar es Salaam, Tanzania.

Muhia, W., Waithera, B., \& Songole, R. (2017). Problems facing Implementation of Public Procurement Regulations in Public Institutions in Kenya: A Case of Nairobi City County Government. International Journal of Business \& Law Research, 4(4),1-11.

Mulwa, J.K., Kalai, J.M., \& Migosi, J. (2015). Determinants of implementation of public procurement regulations in Kenya's secondary schools. International Journal of Educational Research and Reviews, 2(1), 9- 16. 
International Journal of Supply Chain and Logistics

ISSSN 2520-4661 (Online)

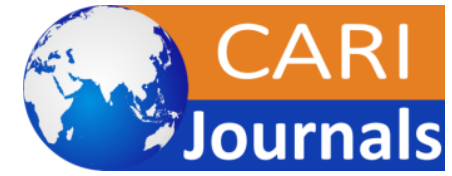

Vol. 4, Issue No.2, pp 104 -128, 2020

www.carijournals.org

Muthoka, C.N. (2016). Procurement Act and performance of government ministries in Kenya (master thesis), University of Nairobi, Kenya.

Mwendwa, M.P., (2013). Factors Influencing Compliance with the Public Procurement Legislation in Kenya, Master Thesis, University of Nairobi. Unpublished.

Njambi, J.N., \& Kihara, A., (2017). Factors Influencing Compliance of Procurement Plans in Public Hospitals in Kenya; A Case of Kenyatta National Hospital, The Strategic Journal of Business \& Change Management, 4(2), 445-460.

Njeru, S.E. (2015). Factors Affecting Effective Compliance of Procurement Practices in Tertiary Public Training Institutions in Kenya, Jomo Kenyatta University of Agriculture and Technology, Unpublished PhD Thesis.

Njogu, G.G., \& Gichinga, L. (2016). Factors Influencing Procurement Performance in State Corporations in Kenya- A Case Study of Kenya Ports Authority, International Journal of Innovative Research and Development, 5(6), 196-251.

Njoroge J., \& Ngugi, E. (2016). Challenges Facing Implementation of Public Procurement Regulations in Public Institutions in Kenya: A Case of Nairobi City County Government. International Journal of Business \& Law Research 4(4):1-11.

Odero, J.A., \& Shiteswa, E.A. (2017). Effect of procurement practices on procurement performance of public sugar manufacturing firms in Western Kenya. International Journal of Management Research \& Review, 7(4), 521-535.

Ogubala, A.R., \& Kiarie, M.D., (2014). Factors Affecting Procurement Planning in County Governments in Kenya: A Case Study of Nairobi City County, International Journal of Economics, Commerce and Management, 2(11), 1-34.

Ombuki, K., Arasa, R., Ngugi, P., \& Muhwezi, M. (2014). Environmental Factors Influencing Procurement Regulatory Compliance by Kenya's Public Universities, International Journal of Social Sciences and Entrepreneurship, 1(9), 407-417.

Onchweri, N.N., \& Muturi, W., (2015). Determinants of Compliance in Public Procurement Regulations in The Public Sector A Case Study of Kisii County, Kenya, International Journal of Economics Commerce and Management, 3(10),749-758.

Orina, S.O. (2017). Financial management. Big Books Ltd. Nairobi.

Voleza, A.D. (2014). Factors influencing implementation of Drafting tender documentation procurement in public institutions: a case of office of the attorney general and department of justice. International Journal of Academic Research in Business and Social Sciences, 4(6), 303-315

Mugerwa, E. (2016). Factors Affecting Supply Chain Performance of SMEs in Eastern Uganda. Kampala.

Ndhlovu, S., \& Twala, W. (2015). Financial needs of small and medium scale contractors in South Africa. Retrieved June 7, 2017, from http://www.cib2007.com/papers 
International Journal of Supply Chain and Logistics

ISSSN 2520-4661 (Online)

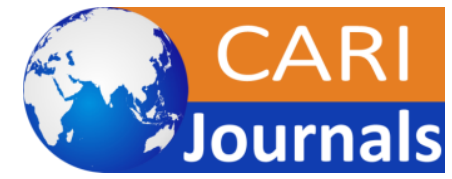

Vol. 4, Issue No.2, pp $104-128,2020$

www.carijournals.org

Ngechu, M. (2016). Understanding the Research Process and Methods. An Introduction to Research Methods. Acts press, Nairobi

Ngugi, J.K., \& Mugo, H.W. (2017). Internal factors affecting procurement process of supplies in the public sector; a survey of Kenya government ministries. Paper presented at 5th International Public Procurement Conference was held on August 17th, 2012 in Seattle, USA. 